Cahiers $d u$ MONDE RUSSE

\section{Cahiers du monde russe}

Russie - Empire russe - Union soviétique et États indépendants

50/2-3 | 2009

L'Europe orientale, 1650-1730. Crises, conflits et renouveau

\title{
ВЫСШИЕ ЧИНЫ ГОСУДАРЕВА ДВОРА ПРИ ПЕТРЕ I
}

(1697-1701)

Les plus hauts grades de la cour de Russie sous Pierre le Grand (1697-1701)

Top-ranking posts at the court of Peter the Great (1697-1701)

\section{Андрей Викт орович Захаров}

\section{(2) OpenEdition}

\section{Journals}

\section{Édition électronique}

URL : https://journals.openedition.org/monderusse/9732

DOI : 10.4000/monderusse.9732

ISSN : $1777-5388$

\section{Éditeur}

Éditions de l'EHESS

Édition imprimée

Date de publication : 15 septembre 2009

Pagination : $579-592$

ISBN : 978-2-7132-2260-3

ISSN : $1252-6576$

\section{Référence électronique}

Андрей Викт орович Захаров, «Высшие чины государева двора при Петре I (1697-1701)», Cahiers du monde russe [Онлайн], 50/2-3 | 2009, Выложить онлайн 13 octobre 2012, Наводить справки в 02 septembre 2022. URL: http://journals.openedition.org/monderusse/9732 ; DOI: https://doi.org/ 10.4000/monderusse. 9732 


\section{ВЫСШИЕ ЧИНЫ ГОСУДАРЕВА ДВОРА ПРИ ПЕТРЕ I (1697-1701)}

Мой интерес, к озвученной теме, возник в связи с продолжающейся публикацией документов Разрядного приказа - повесток думным людям ${ }^{1}$ на боярские съезды 1697-1701 гг. и боярских списков начала XVIII в. ${ }^{2}$ Ключевой вопрос этих проектов о максимально адекватном воспроизведении текста источников решался в нескольких аспектах. Технология публикации и обеспечение эффективного поиска биографических данных о представителях русской элиты определялась возможностями компьютерного программного обеспечения. Точное воспроизведение текста и структуры ранее неопубликованных источников было невозможно без изучения нюансов системы чинов государева двора, которая была традиционной для России XVI-начала XVIII в. Публикация и введение в научный оборот полных текстов служебных списков позволило оперировать массивом биографических данных, которых ранее не было в распоряжении историков. Новые материалы стали основными историческими источниками в попытке решения двух главных вопросов данной статьи. Первый вопрос касается поиска изменений в механизме пожалований и служебных назначений высших чинов государева двора в последние годы их существования. Второй вопрос заключается в изучении отношения русских современников Петра I к восприятию традиционных московских чинов. Для изучения этих проблем большое значение имеет поиск новых методик интерпретации исторических источников. Общие установки концепций абсолютизма, модернизации, распространенных в

1. Для обсуждения проекта на занятиях Школы была предложена база данных «Информационная полнотекстовая система: Повестки думным людям XVII- XVIII вв.», http://zaharov.csu.ru/povestki.pl.

2. Второй проект с 2008 г. называется «Информационная полнотекстовая система: Боярские списки XVIII века». http://zaharov.csu.ru/bspisok.pl. 
российской историографии, оказываются малопригодными, чтобы установить мотивы служебных назначений, определить долю необходимых и искусственных элементов в реформе чинов, и прояснить давний вопрос о статусе чинов государева двора в годы Северной войны (1700-1721 гг.).

Разнообразие трактовок аутентичного понятия «государев двор» можно представить двумя группами мнений в историографии. Некоторые исследователи констатируют его фактическую ликвидацию в связи с прекращением Петром I интенсивных пожалований в традиционные чины московского списка. Другие специалисты считают, что государев двор как социальный институт слабо выражал корпоративное единство и психологию обладателей московских чинов. При толковании понятия «государев двор» используются синонимичные и семантически различные термины: «правящая элита», «боярство», «феодальная аристократия», «чиновная элита», «традиционная элита», «властвующая элита». Многообразие терминологии действительно оправданно, если историк точно сопоставляет эти искусственные конструкции между собой и соотносит их с аутентичными понятиями во множестве смыслов и культурных традиций. Например, в зависимости от контекста, в петровскую эпоху «боярином» мог называться господин вообще, обладатель высшего одноименного чина или любого из четырех думных чинов ${ }^{3}$. Иной семантический ряд представлен в сочинениях иностранцев, для которых «боярин» - это, в том числе, человек, визуально идентифицируемый по боярскому наряду, например, по высокой шапке, сделанной из горловой части меха черно-бурой лисы. Нередко в официальных отчетах иностранных дипломатов даже шут в парадном боярском платье именовался словом «боярин». В описании деловой репутации человека «синклитического сана» ${ }^{4}$, иноземец использовал другое слово - «министр». Этот клубок синонимов и игра смыслов и сейчас становится ловушкой для любого сочинителя, минующего многозначность лексики. Терминологические конструкции историков в обозримой перспективе продолжают конкурировать с другими способами толкования фактов и построения обобщений. Саморефлексия исследователя может помочь расслышать древнего автора. Необходимым условием такой процедуры при дешифровке смысла научного термина становится характеристика стереотипных образов, который он генерирует. Привычные для исследователя искусственные научные термины неизбежно вызывают ряд образов, обусловленных личным, профессиональным или коллективным опытом и системой ценностей. Аутентичные термины и лексика в целом выражают опыт человека XVII в., а ряд образов человека

3. В этом последнем значении слово «боярин» употребляется далее в тексте в кавычках.

4. Синоним, обозначавший человека, обладавшего думным чином. Из русского письма начала XVIII в. 
прошедших эпох и нашего современника не может быть полностью идентичным.

Формулировка темы подтверждает, что отказ от научных неологизмов не ставится задачей статьи. Но анализ терминологии чрезвычайно необходим при изучении судьбы московского государева двора и формирования императорского двора в эпоху Петра I. Высшие чины государева двора - это думные чины: бояре, окольничие, думные дворяне, думные дьяки и высшие дворцовые чины: кравчие, постельничие, стряпчие с ключом. Устоявшаяся формула исторических источников «думные и ближние люди» обозначала чиновные ступени в иерархии и выделяла эти чины от массовых чинов служилых людей: стольников, стряпчих, дворян московских и жильцов. В этимологии научного термина «думные и высшие дворцовые чины», принятого в историографии, очевидно влияние принципа обобщения чинов, принятого в «Табеле о рангах» и сословным законодательством XVIII в. Московское государство XVI- XVII вв., напротив, выделяло служебное различие чинами, дробило эти чины, чтобы различать статус людей. В этом смысле справедливо мнение С.М. Соловьева, который считал, что совмещение московских чинов под общим именем служилых людей ошибочно, поскольку в источниках высшие чины именуются «ближними людьми» и противополагаются низшим «служилым людям» ${ }^{5}$.

Другим научным понятием - «традиционная элита» («служилая элита») в современной литературе дается качественная характеристика «служилых людей по московскому списку». Ценностным стержнем традиционализма являются принципы родовитости, роли прецедентов службы предков человека при назначении его на службу. Принято считать, что ежегодные перечни московских чинов, - боярские списки передают состав государева двора, а его высшие чины представляют элиту Московского государства. Но также в историографии показано, что представления людей XVII в. о чести и идеалах службы ассоциировались не только с записью в боярский список.

Исследователи, применившие методику просопографии в изучении высших чинов государева двора, оперируют понятиями «русская элита», «боярство» или «феодальная аристократия» ${ }^{6}$. Известно, что просопография ориентирована на создание коллективной биографии локальной группы, но при этой методике характер чинопроизводства и зарождение чиновных новаций учитываются не всегда. Статистика чинов ${ }^{7}$ и родового

5. С.М. Соловьев, Исторические письма, М.: изд-во Астрель, 2003; Его же, Сочинения в 18 кн. Кн. XVI. М., 1995, с. 375-376. Таким образом, термин «служилые люди» имеет различный смысл в зависимости от контекста (древнего или современного научного).

6. См. напр.: И.Ю. Айрапетьян, Феодальная аристократия в период становления абсолютизма в России, М. : МГУ, 1988 (дисс. канд. ист. наук).

7. См. напр.: Marshall T.Poe, The Russian Elite in the Seventeenth Century. Vol.2 A Quantitative Analysis of the "Duma Ranks", 1613-1713, Helsinki : FASL, 2004. Работа 
происхождения их обладателей в просопографии может приобрести характер наблюдения за формальными параметрами, которые не выражают действительный статус. С позиций другого, социологического подхода высшие чины государева двора представлены в контексте изменений всей правящей элиты, которая включает бюрократию, ближайшее окружение монарха и фаворитов ${ }^{8}$. При этом устанавливаются факторы изменений служебного учета элиты и социальная мобильность чиновного слоя 9 . На периферии социологического подхода оказываются институты управления, которые рассматриваются как внешнее проявление социальнополитических процессов. Институциональный подход в анализе высших чинов государева двора проявляется попыткой определить структуру, персональный состав элиты, занятой в высших институтах управления. В ущербе оказывается изучение мотивации, моделей поведения элиты, клановые и неформальные связи. Редкие пассажи о служебной карьере, генеалогические экскурсы становятся дополнением к типологии институтов $^{10}$. Перспективы этих подходов, на мой взгляд, в равной мере связаны с расширением базы исторических источников и вниманием к критике аутентичной и научной терминологии.

Источниковой основой данного исследования, как сказано выше, послужила массовая документация оперативного учета службы: повестки думным людям на боярские съезды 1697-1701 гг. (далее - боярские повестки), сказки, боярские списки 1689-1713 гг.; другие служебные и финансовые книги Разрядного приказа. Боярские списки - это основные документы учета чинов государева двора, перечислявшие ежегодно около 6 тыс. человек (для начала XVIII в.). В боярских повестках записывались только сановники, приглашенные на высший совет или придворную церемонию, и проживавшие в одном локальном районе (улице) Москвы. Поэтому они очень компактны, не больше доли листка. Вопросы персональной службы и чиновная картина изучались также по документам личного происхождения. Это сочинения русских авторов (Б.И. Куракин, И.А. Желябужский), иностранных дипломатов и мемуаристов (Г. Грунд, Ю. Юль, О. Плейер, Ч. Уитворт, К. де Бруин, Дж. Перри ${ }^{11}$ ), «Походные журналы» и переписка Петра I.

Маршалла По стала одним из итогов проектирования Биографического банка данных Русского государства XIV-XVII вв. (ББДРГ) международным коллективом историков (О.Е. Кошелева, М. По, М. Ресселл, Б.Н. Морозов).

8. См. напр.: R. Crummey, "Peter and the boyar aristocracy 1689-1700", CanadianAmerican Slavic Studies, 8 (2), 1974, c. 274-287.

9. См. напр.: А.Н. Медушевский, Утверждение абсолютизма в России, М., 1994.

10. См. напр.: Е.В. Анисимов, Верхи русского общества начала петровской эпохи : Правящая элита русского государства ІХ-начала ХVIII в. СПб., 2006, с. 470-497; Он-же, Государственнье преобразования и самодержавие Петра Великого в первой четверти ХVIII в., СПб. : изд-во Д. Буланин, 1997.

11. Г. Грунд (Grund Georg), «Des Kgl. Dänischen Envoyé Georg Grund's Bericht über Russland in den Jahren 1705-1710. Nach dem im Kgl. Dänischen Reichsarchiv zu Kopenhagen befindlichen Originale mitgetheilt von G.L. Grove», Записки императорской 
Делопроизводство по службе высших чинов государева двора велось в Разрядном приказе (Разряде). Подьячие московского стола Разряда оформляли многочисленные назначения на службу, по решению царских советников начисляли поместные и денежные оклады, оповещали о служебных назначениях. В этом отношении приказ фактически заменял канцелярию царя и Думы. Созыв «бояр» на совещания (в Боярскую думу $)^{12}$, организация царских «походов» входили в круг первостепенных дел Разрядного приказа. Интересно, что даже созыв придворных на свадьбу царского шута Филата Шанского исполнялся также подьячими Разряда.

Благодаря подьячим, вносившим в боярские повестки краткие ответы приглашенных людей, мы имеем редкую возможность выяснить подробности о службе и частной жизни вельможи конца XVII в. Встречаются разнообразные пометки: «в полк поехал вчарась», «в доме у него был, ехать нельзя, лошадей нет», «сказал, что у него по матери будет ныне понехида», «по скаске стряпчего Ивашки, что отпущен на неделю в подмосковную вотчину», «поехал молитца Николе в можаискую деревню». Сведения повесток уточняют представления историков о том, что «походом» в русском языке рубежа XVII- XVIII вв. назывались не только выезд царя и его родственников за пределы Кремля, но и поездка думцев по царскому поручению в подмосковные села и монастыри («в походе, в Преображенском» «в походе за царевичем».). Пропуски совещаний и церемоний думцы объясняли преимуществом нового поручения, более важного государю: «сказал, что сего апреля 1-го поедет на Воронеж и о Полате быть некогда»; или своей болезнью: «буде поможетца, будет», «лежит болен, и по отца духовного послано». Подьячие, собиравшие Думу по приказу начальника Разряда боярина Т.Н. Стрешнева, проверяли причины отлучки человека только в двух случаях: при выезде «боярина» из Москвы без отпуска и при нарушении обещания прибыть во дворец. Бояре и придворные в таких случаях были обязаны дать пространное объяснение Разрядному приказу. Более подробные объяснения содержат сказки: «сидел в приказе [...] за приходами и росходами денежнои казны», «не был он в Верх в Полату к боярскому сиденью за мокротною и цынготною своею болезнию [...] и потому он тогда в Верх не был, что был тот день ангела ево хранителя» ${ }^{13}$. Убедительное оправдание пропуска приводилось не

Академии наук по историко-филологическому отделению, 1900, т. 4, № 7; Russland unter Peter dem Grossen: Nach den handschriftlichen Berichten Johann Gotthilf Vockerodt's und Otto Pleyer's, hrgb. E. Herrmann, Leipzig, 1872; Cornelis de Bruin, Reizen over Moskovie, door Persie en Indie..., Amsterdam, 1711; Perry, John, The state of Russia under the present Czar..., London, 1716. О Ю. Юль и Ч. Уитворт, см. ниже сноску 26.

12. Термины источников «бояре», «Дума», и «Полата с бояры» являются синонимами, которые в историографии с начала XIX заменяют неологизмом «Боярская дума». Современный синоним «бояр» - думцы.

13. См.: А.В. Захаров, «А сю сказку писал по велению госуларя своего, (Сказки о службе думных людей в конце XVII века», Вестник Челябинского государственного университета. (История). № 18, 2008, с. 161-172. 
всегда: «не был за забвением и в том волен [поступать] великий государь». Но санкции, видимо, заменялись признанием боярином своей вины. Согласно данным боярских сказок и повесток для думных людей были характерны полная лояльность к царским поручениям и обязательность исполнения службы.

В приказном делопроизводстве жестко соблюдалась чиновная иерархия. Порядок чиновных перечней тщательно прописывались даже в компактных повестках. Внутри каждого чиновного перечня фамилии располагались строго по старшинству пожалования. Формуляр, идентичный повесткам, имели многочисленные списки начала 1690-х гг.: участников походов за святыми иконы», славильщиков ${ }^{14}$ в 1704-1709 гг. Это объяснимо общим происхождением документов, исходивших в изобилии из Разрядного приказа.

Краткую информацию из боярских списков дают пометки о географии назначений, об опале, о физическом состоянии человека, о его владениях крепостными людьми и приписки о пожаловании чином. Технология заполнения учетных списков начала 1720 -х годов не претерпела принципиальных изменений, хотя составлялась в новых учреждениях Сената. Сохранялась иерархия старых московских чинов, а думные чины уже не упоминались. Но учет различных групп служилой элиты стал менее рационален, чем прежде ${ }^{15}$. После введения коллегий в служебных списках появились дробные рубрики по коллежским, губернским и провинциальным учреждениям и отдельным должностям. Петербургские подчиненные конторы герольдмейстера, стольника С.А. Колычева и сенатские чиновники Москвы интуитивно пытались выстроить вертикаль новых учреждений и должностей. В большей мере они действовали по инерции, используя опыт Разрядного приказа.

До сих пор в российской научной литературе и вузовских учебниках широко распространен миф о негативном отношении Петра I к боярству и пожалованию в думные чины. Устойчивость таких трактовок можно объяснить удобным с психологической точки зрения способом восприятия радикальных реформ и принятой антитезой в историографии «старое боярство» - «новое дворянство». Устоявшийся набор аргументов включает свидетельства иностранных наблюдателей, допускавших смелые обобщения и неожиданные экстраполяции ${ }^{16}$.

14. РГАДА (Российский государственный архив древних актов), ф. 210, оп. 22, д. 207, л. 1-6 об.

15. Ситуация сохранялась до именного указа Петра 1722 г., по которому назначения «дворян к каким гражданским делам в которую коллегию или губернии или воеводства» следовали по сенатскому указу с обязательным оповещением герольдмейстера. См.: ПС3 (Полное собрание законов Российской Империи), т. 6, № 3897, с. 499-500.

16. См.: А.В. Захаров, «Государственное управление России начала XVIII века в записках иностранцев», Вестник Челябинского государственного университета, 
Анализ поименных пожалований в высшие чины может приоткрыть мотивы награждений и особенности чиновной механики эпохи реформ Петра I. Вслед за государственным переворотом августа 1689 г. были произведены радикальные перестановки высших сановников. В судьи приказов и «коллегию» думцев, возрожденной Расправной палаты ${ }^{17}$, были назначены активные и лояльно настроенные сторонники Петра I. Интенсивные пожалования в думные чины продолжались около двух лет после переворота $^{18}$. Среди лиц, удостоенных высокой чести в 1695-1698 гг., но уже по личной инициативе царя, были его знаменитые сподвижники А.А. Виниус, кн. Я.Ф. Долгорукий, И.А. Мусин-Пушкин. Награждались и известные участники Азовских походов 1695-1696 гг. Командующий во втором походе корпусом московского дворянства стольник и вологодский воевода кн. П.Г. Львов, назначенный воеводой покоренной крепости, в тот же день получил чин окольничего ${ }^{19}$. Список окольничих пополнили начальник «у провиантских дел» думный дворянин С.И. Языков и воевода думный дворянин В.Б. Бухвостов, успешно оборонявший от крымских татар завоеванную крепость Тамань в 1697 г. $^{20}$. Закономерно сложилась дальнейшая карьера азовских героев. Спустя год, они были видны в кремлевских палатах и в Думе ${ }^{21}$. Языков возглавил с 1700 г. Провиантский приказ в изобретенной должности генерал-провианта. На следующий год Бухвостов отправился в г. Псков укреплять крепость и ведать ратными людьми ${ }^{22}$. По-прежнему сохранялась традиция объявлять думное звание в Великие церковные праздники ${ }^{23}$ и знаменательные даты. В день рождения царя 30 мая 1701 г. думное дворянство было пожаловано И.И. Исленьеву, через месяц, в Петров день - Н.М. Зотову (в связи с назначением судьей Печатного приказа). Трудно объяснить только выбор даты пожалования

(История. Серия 7). Государственное и муниципальное управление, № 1, 1998, с. 2728.

17. Расправная палата 1689-1694 гг. существовала как особая комиссия «бояр», но с 1706 достоверно прослеживается работа кн. М.А. Черкасского «у росправных дел», как воеводы Москвы, а не в качестве председателя одноименной комиссии или палаты, как ошибочно полагают некоторые историки. См.: РГАДА. ф. 210, оп. 8, связка 8, д. 39 , л. 1 ; связка 44 , д. 48, л. $1-4$.

18. С сентября по декабрь 1689 г. состоялось 4 пожалования в думные чины, в 1690 г. - 23 в думные и 2 в высшие дворцовые чины, в 1691 г. - 21 в думные и 1 в высшие дворцовые чины, в 1692 - 9 в думные чины, в 1693 - 7 в думные чины, в 1694 г. пожалований не было. См.: РГАДА, ф. 210, оп. 2, д. 30-36.

19. ДР (Двориовые разряды), т. 4, с. 970.

20. См. И.А. Желябужский, Россия при царевне Софье и Петре I, Записки русских людей, М., 1990, с. 258, 290.

21. См.: http://zaharov.csu.ru/povestki.pl (Перечень фамилий/Бухвостов; Львов; Языков).

22. ПиБ (Письма и бумаги Петра Великого), т. 2, СПб., 1889, с. 448.

23. П.Г. Львову в праздник Успения Пресвятой Богородицы (15 августа 1696 г.), С.И. Языкову в Благовещение Пресвятой Богородицы (25 марта 1697 г.), В.Б. Бухвостову — «в навечерии праздника Усекновения главы святого пророка предтечи и крестителя Иоанна» (28 августа 1698 г.). 
совершенно нового звания, чина думного советника П.Б. Возницыну, который заключил перемирие с турками. «Июня в 26 день [1701 г. - А.3.] великий государь пожаловал ево, велел в боярских книгах и списках и во всяких письмах писать ево с вичем [то есть полным отчеством. - А.3.] выше думных дьяков» ${ }^{24}$. С начала Северной войны список думцев не пополнялся восемь лет.

Хотя в начале нового века были внедрены новые титулы, чины, должности и орденская система, тем не менее, остались заметны и другие новации в системе прежних чинов. В закрытую чиновную систему XVIII в. безболезненно было привито достижение одной из дипломатических миссий в Европу. Эхо пребывания Б.П. Шереметева в 1698 г. на Мальте повторялось в боярских списках 1701-1713 гг. формулой «боярин и военной кавалер мальтийской свидетельствованной». Удивительно быстро новая лексика разбавила формуляр списка московских чинов. Чиновные перечни, составленные после победы под Полтавой, запестрели новыми словами, непривычными для человека той поры: «генеральный презыдент и московской комендант и Сибирских правинций судия» (кн. М.П. Гагарин), «постельничий, государственный канцлер, тайной советник и ковалер» (Г.И. Головкин), боярин «в Сенате тайной советник, генерал пленипотенциаркрикъкамисар» (кн. Я.Ф. Долгорукий), стольник комнатный «генерал рыденбант Святаго апостола Андрея» (кн. Н.И. Репнин) ${ }^{25}$.

Иностранные дипломаты, оказавшиеся в России, по-своему объясняли мотивы введения новых почетных титулов, - «амбициями царя, которые растут вместе с его успехами». Датский посланник Ю. Юст высмеивал отношение царских министров к европейской титулатуре, якобы дающей больший почет. С иронией он описал людей, желавших этим «косвенно показать, что царство их государя - империя». Более лояльный к царской администрации Г. Грунд в 1710 г. точно спрогнозировал реформу чинов: «...царь пока и не обнародовал какого-либо настоящего порядка рангов, а все еще приказывает дорабатывать его проект, так что это дело, вероятно, не будет закончено до заключения мира» ${ }^{26}$.

Посмотрим, насколько окончательно и легко Петр I и его окружение расстаются с атрибутами боярства? Пожалование казанского губернатора

24. РГАДА, ф. 210, оп. 2, д. 45, л. 10 (Боярский список 1701 г.).

25. Там-же, д. 58, л. 3 об., 5, 2, 9 об. (Боярский список 1711 г.).

26. Россия в начале XVIII в.: Сочинение Ч. Уитворта, изд. и перевод Н.Г. и Ю.Н. Беспятых, М.-Л., 1988, с. 67 [с английского: Lord Charles Whitworth, An Account of Russia As It Was in the Year 1710, Strawberry Hill Press, MDCCLVIII]; Ю. Юль, Записки датского посланника в России, перевод с датского осуществлен Ю.Н. Щербачевом с датской рукописи // Лавры Полтавы, М., 2001, с. 137 ; см. Just Juel, En rejse til Rusland under tsar Peter, dagbogsoptegnelser af viceadmiral Just Juel, dansk Gesandt $i$ Rusland 1709-1711, med... oplysende anmaerkninger ved Gerhard L. Grove, København, F. Hegel og son, 1893; Г. Грунд. Доклад о России в 1705-1710 г2., перевод Ю.Н. Беспятых, с немецкого (Georg Grund, ук. соч.). М.-СПб., 1992, с.137. 


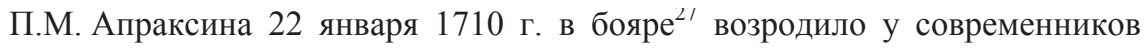
впечатление доступности думных званий. Ряд фактов говорит о неоднозначном отношении царя к ним. По всей видимости, пожалования 10 человек в 1710-1712 гг. - это результат ходатайств к царю с просьбой заветного чина. Также настойчиво, в 1715 г. боярин П.М. Апраксин испрашивал у царя уже новый графский титул. Среди сановников, получивших думные чины, оказались люди различного социального статуса: родственники и близкие царской семьи, и... «шуты» ${ }^{28}$. В петровских письмах и походных журналах царя кн. Ю.Ф. Шаховской, К.Х. Патрикеев, П.А. Ушаков, С.Я. Тургенев, П.И. Бутурлин названы «дураками». Так называли шутов, забавлявших царя и остроумными, и грубыми шутками, и особым умением разоблачать прегрешения придворных. Самый язвительный критик петровского окружения кн. Б.И. Куракин так описал «таланты» кн. Ю.Ф. Шаховского «был ума немалого и читатель книг, токмо самой злой сосуд и пьяной» ${ }^{29}$. Мотивы награждения других стольников: П.В. Бутурлина, кн. М.Ф. Шаховского, кн. Н.М. Жирового-Засекина, которым также не запрещались сумасбродные забавы на всепьянейших соборах, остаются пока загадкой ${ }^{30}$. Известно, что они не состояли в «постоянном штате» царских шутов. Прецедент возведения слуги-весельчака на высокую чиновную ступень, создал царь Алексей Михайлович, наградивший за долгую службу своего шута кн. И.А. Жирового-Засекина чином московского дворянина ${ }^{31}$. Не вписывается в ряд шутовских наград награждение чином окольничего стольника А.А. Юшкова, служившего в армии ${ }^{32}$. О нем царь своей рукой приписал в указе Сенату 4 ноября 1711 г.: «За многия и чрезвычайныя службы у служения и радения в върученных ему делех пожаловать сею честию (выделено мной - А.3.)» ${ }^{33}$. По мнению историка М.И. Семевского о награждении хлопотала царица Прасковья Федоровна ${ }^{34}$. Любопытным казусом можно считать запись Ф.М. Апраксина в 1713 г. в список бояр, но

27. РГАДА, ф. 210, оп. 2 (Боярские списки), д. 57, л. 2 об.

28. Пожалованы в бояре: кн. Ю.Ф. Шаховский (12 апреля 1710 г. из комнатных стольников), П.И. Бутурлин (20 апреля 1712 г. из стольников); в думные дворяне: К.Х. Патрикеев (12 апреля 1710 г. из «ближних людей»); П.А. Ушаков (14 января 1711 г. из стряпчих), С.Я. Тургенев (28 января 1712 г. из стольников) См.: Там-же, д. 57, л. 2 об., 4 об. ; д. 58, л. 2, 6 об.

29. Г. Грунд, ук. соч., с. 129 ; Ю. Юль, ук. соч., с. 85 ; Б.И. Куракин, Гистория о Петре I и ближних к нему людях: Русская старина, 1890, т. 68, № 10, с. 256.

30. П.В. Бутурлин пожалован в думные дворяне 12 апреля 1710 г. из стольников. 20 апреля 1712 г. в окольничие пожалованы: кн. М.Ф. Шаховской, кн. Н.М. ЖировойЗасекин (оба из комнатных стольников) и П.В. Бутурлин (из думных дворян). См.: РГАДА, ф. 210, оп. 2, д. 57, л. 6; д. 58, л. 4 об.

31. Н.М. Молева, Э.В. Белютин, Живописных дел мастера, М., 1965, с. 15.

32. РГАДА, ф. 210, оп. 2, д. 58, л. 22 об. Шутом Петра I был Александр Юшков.

33. ПиБ, т. 11/2, с. 236. Ср.: РГАДА, ф. 210, оп. 2, д. 58, л. 4 об.

34. См.: М.И. Семевский Царица Прасковья, М., 1989, с. 23-24. 
специальный указ об этом не известен. Адмирал записан в списке бояр выше старшего брата, хотя боярство П.М. Апраксин получил раньше . $^{35}$

С новыми указами о пожаловании в думные чины царь обращался к Сенату, а решения по-прежнему заносились в боярские списки. В выборе монархом даты и чина награждения, в стилистике указов отражены старинные каноны. Три пожалования последовали в день Светлой недели и четыре - в день Пасхи. Выбор чина целиком соответствовал принципу родовитости. Например, из живших на тот момент Бутурлиных высшими думными чинами были пожалованы двое самых старших представителей рода. Петр I соблюдал и последовательность награждения. П.В. Бутурлин был пожалован сначала в думные дворяне, через год в окольничие. Самые высшие московские чины - боярина и окольничего получили только представители боярских и княжеских родов. Менее родовитые служилые люди, из стольников, стряпчих и дворян не записывались выше чина думного дворянина ${ }^{36}$.

В письмах царя и его современников не встречается прозвание шутов думными людьми. Но практически вся чиновная верхушка и придворные испытывали метаморфозы пародийной игры, в которой сам царь носил эпатажное шутовское прозвище. Нашим современникам легко принять пожалования «шутов» за оригинальную насмешку Петра I над старыми чинами. Но замечу, что упрощенные рассуждения о неприятии царем думных чинов до сих пор остаются не доказательными. Петру I приходилось считаться с «популярностью» высших чинов государева двора. Назначения нескольких «шутов» или участников всепьянейшего собора в думные чины совсем не шутовская пародия на старые «отжившие» чины. Это логическое завершение «инфляции почестей» тенденции, наметившейся с начала 1690-х гг., при которой высший чин не сообщал реальный статус царского советника.

С началом войны со Швецией (1700-1721 гг.) изменились формы институтов высшего управления. В 1702 г. прекратились заседания боярских советов из полного состава думных чинов. Но сами чины, как и служба советников, не упразднялись. Царю, редко бывавшему в Москве, потребовался компактный совет из «бояр», исполнявших экстренные поручения. Изучение службы бывших думцев в высших государственных советах в те военные годы до сих пор затруднено противоречивыми выводами в историографии. Изобретение научных неологизмов «Боярская дума», «члены Думы» ${ }^{37}$, «боярская комиссия в Ближней Канцелярии» ведет к ряду принципиальных искажений подлинных терминов той эпохи. К

\footnotetext{
35. РГАДА, ф. 210 , оп. 2, д. 60, л. 4 об.

36. Только К.Х. Патрикеев числился вне московского списка, но «из ближних людей».

37. Под этим неологизмом очень часто подразумеваются обладатели думных чинов, а не реальные участники высших совещаний.
} 
сожалению, использование неологизмов порождает ошибки и мифы в научной литературе.

Первое заблуждение состоит в смешении списочного состава думных чинов с перечнем реальных царских советников, который к концу XVII в. был в 2-3 раза меньше всего списка. Это убедительно доказал M.M. Богословский ${ }^{38}$. Чинопроизводство в думные чины с начала XVIII в. окончательно оторвалось от назначения в высшие учреждения. По недоразумению, в некоторых научных публикациях 1713 г. - время составления последнего сохранившегося подлинного боярского списка объявляется верхней границей существования государева двора и даже Боярской думы. Но такая формальная датировка не выдерживает критики. В книгах Сената неоднократно сообщается о подготовке и наличии боярских списков 1714-1720 гг., которые, видимо, были утрачены в московском пожаре 1812 г. ${ }^{39}$ Учет высших чинов государева двора велся практически до 1721 г. $^{40}$, что вполне отвечало назначению старой служебной документации.

Вторая распространенная ошибка состоит в противопоставлении Боярской думы с различными формами боярской службы в высших государственных советах, которые также назывались консилиями. Другая крайность состоит в смешении консилий с Ближней канцелярией. Дело в том, что боярские приговоры (решения) вплоть до учреждения Сената в феврале 1711 г. могли состояться во время консилий без участия царя, в Москве или в подмосковных резиденциях, или в военном походе Петра I. C 1702 г. чаще всего боярские совещания проходили в стенах кремлевской Ближней канцелярии. Под таким названием в 1701 г. Петр I учредил финансовую ревизионную службу. Это был фактически возрожденный Счетный приказ царя Алексея Михайловича, который стал в руках петровских «бояр» идеальным средством измерения пульса казны. Боярская «коллегия» принимала решения, используя бюрократические механизмы и штат Ближней канцелярии, для исполнения указов царя. Персональный состав и решения этого совета «бояр» ${ }^{41}$ впервые достоверно прослеживаются только с 1703 г. В 1705 г. чиновникам Ближней канцелярии поручалось составление книг с записью всех царских указов и

38. М.М. Богословский, Петр I. Материаль к биографии, т. 4, М., 1948, с. 256.

39. Доклады и приговоры правительствующего Сената, т. 3/2, СПб., 1888, с. 844; т. 4/2, СПб., 1891, с. 670,1182 ; т. 5/2, СПб., 1897, с. 453, 513, 556; РГАДА, ф. 248, оп. 12 , д. 648 , л. 11,41 ; д. 649 , л. 113.

40. По архивным данным, приведенным Лукичевым, боярский список 1714 г. пополнялся записями еще несколько лет, в том числе в 1718 г. См.: М.П. Лукичев, Боярские книги ХVII в., М., 2004, с. 105. К настоящему времени удалось выявить раннюю копию этого документа.

41. РГАДА, ф. 19, оп. 1, д. 1, отд. 8, л. 18-19 ; отд. 4, л. 120-120 об. 
решений боярских советов. Самые ранние такие книги за 1705-1711 гг. ${ }^{42}$, по-видимому, были утрачены к началу ХІХ в. Поэтому реконструкция повседневной практики консилий - этого уникального переходного института управления осложнена отсутствием единого фонда документов высших учреждений 1700-февраля 1711 гг. в современных архивах. За 1703 г. удалось восстановить датировку и содержание 27 приговоров ${ }^{43}$ «бояр» и только 5 из них раскрывают имена нескольких участников: бояре Ф.А. Головин, Т.Н. Стрешнев, кн. П.И. Прозоровский, кн. И.Б. Троекуров, окольничий А.Т. Лихачев, думный дворянин и печатник Н.М. Зотов, думные дьяки А.А. Виниус, Г.Ф. Деревнин, Л.А. Домнин и комнатный стольник кн. Ф.Ю. Ромодановский. Состав боярских совещаний изменялся в сторону преобладания судей (начальников) приказов, поэтому они именовались «боярами» или «министрами». Большинство дел 1703 г. касались пере-распределения финансовых средств между приказами, такие полномочия имели только участники консилий, при условии коллегиального обсуждения. Петр буквально атаковал консилии требованиями срочного поиска денег для снабжения армии припасами, для выплаты жалования служилым людям. Кроме того «министры» руководили подавлением бунта донских казаков во главе с К. Булавина, укреплением городских крепостей в Воронеже, в Троицком. Боярские консилии мало похожи на боярские комиссии XVII в., управлявшие Москвой во время кратких выездов царя из Кремля. Таким образом, Боярская дума при Петре I имела разные формы работы, а точнее сказать, «бояре» созывались на совещания различных форм, одной из которых и стали консилии.

Служба высших чинов Двора могла проходить и за пределами Москвы. Поэтому важно обратится к статистике поручений вне столицы, сравнивая рубежные десятилетия XVII и XVIII вв. ${ }^{44}$ Основной в 1690 -е гг. была городовая служба на посту воевод и товарищей (заместителей) воевод. Из 33 городов и уездов, которыми руководили в 1690-е гг. 57 обладателей высших чинов, 17 городов имели статус «наместничьих» ${ }^{45}$. После второго Азовского похода 9 думных людей назначались воеводами в Азов, Таганрог, Тавань, Казыкермен. Поручения 24 человек отмечены в 35 менее крупных населенных пунктах. В первом десятилетии XVIII в. доля службы городовых воевод снизилась почти троекратно с 30 до $11 \%$ от списочного

42. В сохранившемся сборнике подлинных указов Петра I указано сделать список с царского письма и переплести в «книгу с ымянными ж указами и боярскими приговорами 1706 году». См.: РГАДА, ф. 1451, оп. 1, д. 1, л. 12.

43. См.: А.В. Захаров, Трансформаџия высших государственных учреждений России конца XVII-начала XVIII в., Дисс. канд. ист. наук, Челябинск, 1999, с. 225-227.

44. Статистика основана на данных боярских списков, переписки царя и записок современников. В 1690-1700 гг. нестоличная служба зафиксирована боярскими списками у 70 человек из 188 представителей думных и высших дворцовых чинов, а в 1701-1711 гг. у 43 из 105 человек.

45. Список городов см.: Проект устава о служебном стариинстве бояр, окольничих и думных людей по 34 степеням, сообщ. кн. М.А. Оболенским, М., 1850, с. 12-18. 
состава высших чинов. Но в крупные города по-прежнему назначались воеводы с думным званием. Доминировали во время Северной войны служебно-полковые назначения, возросшие с 8\% за 1690-е гг. до 31 \% в 1701-1711 гг. Эти назначения в XVIII в. отличались рекрутированием думных людей с малым опытом полковой службы и стремительным ростом числа командующих гарнизонами городов-крепостей. Практически не изменилась доля дипломатических поручений (3,7 \% в 1690-е гг. и 4,7 \% в 1700-е гг.). Военное лихолетье сказалось и на увеличении с 3 до 8 \% чрезвычайных (экспедиционных) ${ }^{46}$ поручений думным людям. Статистика службы высших чинов государева двора вне столицы опровергает тезис советской историографии о «враждебности и оппозиционности боярской аристократии». Традиционная служилая элита действительно составила важную социальную силу преобразований Петра I.

Итак, после Азовских походов практика думных пожалований из средства массового отличия лояльно настроенной служилой элиты трансформировалась в способ персонального выделения талантливых воевод и приказных дельцов. Обладание думным званием окончательно оторвалось от возможности пребывать в Думе. Это послужило одной из главных причин «бархатного переворота» 1702 г. в московском правительстве. В результате этого бескровного и внешне незаметного события совещания всех думных людей, находившихся в Москве, целиком уступили место коллегиальным советам узкой группы советников. Характер последних пожалований в думные чины согласуется, во-первых, со стремлением Петра I внедрить новые чины и титулы и демонстрирует заинтересованность царя в сохранении традиционных высших чинов до 1720-х годов. Во-вторых, последние пожалования демонстрируют популярность старых московских чинов, несмотря на то, что они не сообщали права участия в высших государственных советах.

Таким образом, механизм обеспечения службы высших чинов на рубеже XVII-XVIII вв. включал систему чинопроизводства, институты сообщения и контроля служебных поручений. Учет чинов в традиционной системе государева двора фактически сохранялся до введения «Табели о рангах». Взаимодействие систем осуществлялось Разрядным приказом, а с 1711 г. разрядным столом Сената служебная документация которого быстро впитывала новые элементы в старую чиновную иерархию. Служебные назначения чинов государева двора оставались массовыми, прежде всего, на военную службу, и потребовали создание более оперативной полковой документации, которая оказалась наиболее адекватной для регулярной армии.

46. К этому виду службы условно отнесены ревизии воеводского управления, сбор различных припасов для Дворца, набор рекрутов, снаряжение действующей армии, подавление восстаний 1705-1708 гг. 
Причудливое «переплетение» традиционных и новых чинов, - их одновременное бытование в первых служебных списках Герольдмейстерской конторы стало нормой последних лет петровского царствования. С прекращением в 1721 г. специального учета старых чинов произошла рецепция (заимствование) приказных способов служебного контроля Сенатскими учреждениями, а приказная документация активно использовалась в государственном делопроизводстве вплоть до конца XVIII в.

Université de Tchéliabinsk

Faculté d'histoire

elural@yandex.ru 